\title{
Prevalence and diversity of enteric pathogens among cholera treatment centre patients with acute diarrhea in Uvira, Democratic Republic of Congo
}

Camille Williams $^{1^{*}}$ (D) Oliver Cumming ${ }^{1}$, Lynn Grignard ${ }^{2}$, Baron Bashige Rumedeka ${ }^{3}$, Jaime Mufitini Saidi ${ }^{3}$, Daniel Grint ${ }^{4}$, Chris Drakeley ${ }^{2}$ and Aurelie Jeandron ${ }^{1}$

\begin{abstract}
Background: Cholera remains a major global health challenge. Uvira, in the Democratic Republic of the Congo (DRC), has had endemic cholera since the 1970's and has been implicated as a possible point of origin for national outbreaks. A previous study among this population, reported a case confirmation rate of $40 \%$ by rapid diagnostic test (RDT) among patients at the Uvira Cholera Treatment Centre (CTC). This study considers the prevalence and diversity of 15 enteric pathogens in suspected cholera cases seeking treatment at the Uvira CTC.
\end{abstract}

Methods: We used the Luminex XTAG ${ }^{\circledR}$ multiplex PCR to test for 15 enteric pathogens, including toxigenic strains of $V$. cholerae in rectal swabs preserved on Whatman FTA Elute cards. Results were interpreted on MAGPIX ${ }^{\circledR}$ and analyzed on the XTAG ${ }^{\circledR}$ Data Analysis Software. Prevalence of enteric pathogens were calculated and pathogen diversity was modelled with a Poisson regression.

Results: Among 269 enrolled CTC patients, PCR detected the presence of toxigenic Vibrio cholerae in 38\% (103/269) of the patients, which were considered to be cholera cases. These strains were detected as the sole pathogen in $36 \%(37 / 103)$ of these cases. Almost half (45\%) of all study participants carried multiple enteric pathogens (two or more). Enterotoxigenic Escherichia coli (36\%) and Cryptosporidium (28\%) were the other most common pathogens identified amongst all participants. No pathogen was detected in $16.4 \%$ of study participants. Mean number of pathogens was highest amongst boys and girls aged 1-15 years and lowest in women aged 16-81 years. Ninetythree percent of toxigenic $V$. cholerae strains detected by PCR were found in patients having tested positive for $V$. cholerae $\mathrm{O} 1$ by RDT.

Conclusions: Our study supports previous results from DRC and other cholera endemic areas in sub-Sahara Africa with less than half of CTC admissions positive for cholera by PCR. More research is required to determine the causes of severe acute diarrhea in these low-resource, endemic areas to optimize treatment measures.

(Continued on next page)

\footnotetext{
* Correspondence: cwills111@gmail.com

'Department of Disease Control, Faculty of Infectious and Tropical Diseases,

London School of Hygiene and Tropical Medicine, Keppel Street, London

WC1E 7HT, UK

Full list of author information is available at the end of the article
}

(C) The Author(s). 2020 Open Access This article is licensed under a Creative Commons Attribution 4.0 International License, which permits use, sharing, adaptation, distribution and reproduction in any medium or format, as long as you give appropriate credit to the original author(s) and the source, provide a link to the Creative Commons licence, and indicate if changes were made. The images or other third party material in this article are included in the article's Creative Commons licence, unless indicated otherwise in a credit line to the material. If material is not included in the article's Creative Commons licence and your intended use is not permitted by statutory regulation or exceeds the permitted use, you will need to obtain permission directly from the copyright holder. To view a copy of this licence, visit http://creativecommons.org/licenses/by/4.0/ The Creative Commons Public Domain Dedication waiver (http://creativecommons.org/publicdomain/zero/1.0/) applies to the data made available in this article, unless otherwise stated in a credit line to the data. 
(Continued from previous page)

Trial registration: This study is part of the impact evaluation study entitled: "Impact Evaluation of Urban Water Supply Improvements on Cholera and Other Diarrheal Diseases in Uvira, Democratic Republic of Congo" registered on 10 October 2016 at clinicaltrials.gov Identification number: NCT02928341.

Keywords: Cholera, Diarrhea, Enteric pathogens, Sub-Sahara Africa, Endemic

\section{Background}

In 2016, infectious diarrheal diseases were estimated to be the eighth leading cause of global mortality, attributing to 1.6 million deaths, and the third leading cause of disability-adjusted life years (DALYs) [1]. Diarrheal morbidity and mortality are concentrated in low and middleincome countries (LMICs) with the highest burden in South Asia and Sub-Sahara Africa (SSA) [2]. Children under five years of age bear most of this burden with diarrheal diseases in early life often leading to malnutrition, growth faltering, cognitive shortcomings, and vitamin deficiencies [2-4].

Diarrheal diseases of infectious origin are predominantly caused by enteric pathogens (including bacteria, viruses, protozoa, and fungi) that are transmitted by oral-fecal routes via ingestion of contaminated food, water or via dirty fingers or fomites, and shed in human and animal feces [5]. Diarrhea caused by the bacterium Vibrio cholerae is of particular global concern. In 2015, cholera was endemic in over 47 countries and outbreaks continue to resurface in conflict zones and after natural disasters, such as the outbreaks previously seen in Yemen, South Sudan and Haiti $[6,7]$. Severe cholera illness is identified by symptoms of severe dehydration and acute watery diarrhea, defined as three or more loose liquid stools in $24 \mathrm{~h}$, and if untreated, can be fatal within hours of symptom onset [8]. During the first few hours of symptom onset, cholera can be hyper-infectious and person-to-person transmission can increase [9]. However, a large proportion of infections remain asymptomatic and carriers still shed $V$. cholerae but at a lower dose [10]. Cholera particularly affects areas with limited drinking water and sanitation infrastructure [7]. Globally, the highest incidence of cholera is reported in inland Sub-Sahara Africa, particularly in Eastern Democratic Republic of the Congo (DRC) and Western Uganda regions [11, 12].

In 2017, the Global Task Force for Cholera Control (GTFCC) launched a new "Global Roadmap" to reduce cholera mortality by $90 \%$ globally and to eliminate cholera in as many as 20 countries by 2030 [8]. This new global strategy led by WHO has three components: (1) early detection and response to outbreaks; (2) a multisectoral approach targeting cholera "hotspots"; and (3) effective coordination of support efforts at local and global levels. Comprehensive efforts to control cholera include: ensuring access to safe drinking water and sanitation, and associated hygiene practices; effective treatment for patients, including oral, or intravenous rehydration therapy; and antibiotic treatment for severe cases. In addition to these interventions, safe and effective oral cholera vaccines $(\mathrm{OCV})$ are now available and recommended in many settings $[13,14]$; although timely distribution can be challenging due to limited global stockpiles, and the security and logistical challenges inherent to many cholera-affected areas $[6,14,15]$.

As part of an ongoing trial (the "Uvira Trial") to evaluate the impact of improved piped water supply in Uvira on cholera and other diarrheal diseases started in 2016, our study investigates enteric pathogens among suspected cholera patients admitted to a Cholera Treatment Centre (CTC) in Uvira, DRC using a commercial multiplex polymerase chain reaction (PCR) on rectal swabs collected over a nine-month period. The specific objectives are to: (1) quantify the prevalence of enteric pathogens among suspected cholera cases; (2) describe the diversity of enteric pathogens among these patients; and (3) compare confirmation of cholera by PCR and rapid diagnostic test (RDT) methods.

\section{Methods \\ Study setting}

Uvira is a city within the province of South Kivu on the eastern side of the DRC along the shores of Lake Tanganyika in the African Great Lakes region with an estimated 233,000 inhabitants in 2017 [16]. Decades of protracted conflict resulting in population displacement combined with limited public health infrastructure have hampered national and international efforts for cholera control in eastern DRC [17]. The African Great Lakes region has been implicated in the spread of outbreaks to other parts of the country and Uvira, in particular, has had endemic cholera since the 1970s [18]. The only CTC in Uvira is located within the district hospital to provide appropriate free treatment for all patients presenting acute diarrhea, defined as: three or more loose/ water stools within $24 \mathrm{~h} \mathrm{[19].} \mathrm{All} \mathrm{cases} \mathrm{admitted} \mathrm{are} \mathrm{re-}$ ported as cholera cases in the National Health Information System (NHIS) and are treated by national protocol for suspected cholera, receiving rehydration therapy and, occasionally, broad-spectrum antibiotics, zinc, or albendazole [19]. A recent linked study to confirm cholera 
cases by RDT among patients at the Uvira CTC found that only $40 \%$ tested positive [19].

\section{Sampling strategy and data/sample collection}

The sampling and recruitment procedures have been described previously [19]. In brief, basic demographic and clinical information for each participant were extracted from CTC patient records, including: age, sex, location of residence, date of admission, date of discharge or transfer, symptoms, and whether the patient received antibiotics prior to rectal swab collection and, if so, the number of hours between first dose and the rectal swab collection. All data were anonymized and entered onto a password-protected tablet by trained researchers and then uploaded to a secure Open Data Kit (ODK) server, and the data then deleted from the tablet.

A trained laboratory technician collected a rectal swab for all new, consenting patients in the morning, seven days a week. The rectal swab was then immediately eluted in $1 \mathrm{ml}$ sterile physiological water for approximately $10 \mathrm{~s}$ and lightly shaken before a part is transferred to alkaline peptone water (APW) for an enrichment stage of $6 \mathrm{~h}$ before Crystal VC RDT testing (Crystal VC, Span Diagnostics, Surat, India). In parallel, four drops of physiological water (each approximately $40 \mu \mathrm{l}$ ) were preserved on Whatman FTA Elute cards (GE Life Sciences, Piscataway, NJ USA). Once dry, the cards were stored at room temperature in an individual zipped plastic pouch containing a $1 \mathrm{~g}$ packet of desiccant silica gel. Previous studies evaluated Crystal VC RDT sensitivity and specificity to be 92 and $91 \%$, respectively [20] and confirmed the effectiveness of Whatman FTA Elute cards (GE Life Sciences, NJ USA) for preservation of nucleic acid for future multiplex PCR analysis [21]. The preserved samples were shipped to the London School of Hygiene and Tropical Medicine for laboratory analysis under the UN3373 infectious substance EXEMPT regulations and under a Material Transfer Agreement (MTA) with the Ministry of Health for DRC.

\section{Laboratory analysis: DNA extraction and PCR}

The Luminex $\mathrm{xTAG}^{\circ}$ Gastrointestinal Pathogen Panel (GPP) was used to analyze the FTA Elute cards for the presence of 15 enteric pathogens: adenovirus, Campylobacter, Clostridium difficile, Cryptosporidium, Entamoeba histolytica, Escherichia coli O157, Enterotoxigenic Escherichia coli (ETEC) LT/ST, Giardia, norovirus GI/GII, rotavirus A, Salmonella, shiga toxin-producing Escherichia coli (STEC), Shigella, toxigenic Vibrio cholerae, and Yersinia enterocolitica (Luminex Corporation, Austin TX, USA) [22]. The GPP kit is a validated [23-25] commercial real-time PCR assay for the stool-based detection of these pathogens and has been used in various settings [26, 27].
Nucleic acid was extracted from the Whatman Elute Cards using the GE Healthcare Life Sciences protocol (N) USA) [28]. We added one $\mu \mathrm{L}$ of bacteriophage MS2, the internal control provided by $\mathrm{xTAG}^{\circ}$ GPP to each sample during the wash stage of extraction process, as advised by Luminex ${ }^{\circ}$. PCR amplification and hybridization were conducted according to the supplier's protocol (Luminex Corporation, Austin TX, USA). Results were interpreted on MAGPIX $^{\circ}$ and analyzed on the $\mathrm{xTAG}^{\circ}$ Data Analysis Software (Luminex Corporation, Austin TX, USA).

\section{Statistical analysis}

All statistical analyses were conducted in STATA version 15 (Stata Corporation, College Station, TX, USA).

The prevalence, and corresponding 95\% confidence intervals, for detected enteric pathogens were calculated and stratified by a demographic group, combining both sex and age groups. Poisson regression for count data was used to describe the diversity of enteric pathogens stratified by the demographic group. Robust standard errors were used to control for minor variations from underlying assumptions [29]. The deviance $\chi^{2}$ and Pearson $x^{2}$ goodness of fit tests were used to determine whether data fitted a Poisson distribution. The incident rate ratios (IRR) were recorded along with corresponding $p$-values for a two degrees-of-freedom test. Univariate logistic regression was used to determine if the age and sex demographic group was associated with $V$. cholerae detection. Antibiotic treatment prior to sample collection was identified as a potential source of bias a priori as a single dose of antibiotics can be absorbed in the body in as few as $3 \mathrm{~h}$ [30] and, therefore, included in both Poisson and logistic regressions to assess if antibiotic administration influenced the statistical analysis.

Crystal $^{\circ}$ VC RDT (Span Diagnostics, Surat, India) detects $\mathrm{O} 1 / \mathrm{O} 139$ antigens of $V$. cholerae strains whereas the Luminex $\mathrm{xTAG}^{\circ} \mathrm{GPP}$ targets the $c t x$ gene coding for the cholera toxin, therefore detecting toxigenic $V$. cholerae strains. Discordant pairs for cholera RDT and multiplex-PCR with elute cards were identified. The McNemar $x^{2}$ test was used to test for marginal homogeneity between these two diagnostic methods.

There were no missing data for any statistical analyses. The corresponding anonymized raw data can be found in Additional File 1.

\section{Results}

Characteristics and demographics of study participants

Between 24 September 2017 and 09 July 2018, 269 patients admitted to the CTC were enrolled into the study. No patients were enrolled into the study between 11 December 2017 and 11 February 2018 due to a shortage of supplies. Sixty-three percent of study participants were over the age of 15 . Sex was evenly distributed amongst 
study participants (female $n=132$; and male $n=137$ ). Among the participants, 27 (11\%) had received antibiotics with a mean time between treatment and sample collection of $6.26 \mathrm{~h}$. Antibiotic treatment was not associated with either the mean number of pathogens present $(p=0.2)$ or $V$. cholerae detection $(p=0.3)$.

\section{Prevalence and diversity of enteric pathogens}

Multiplex-PCR detected 37\% (100/269) of all samples were positive for a single pathogen only. Amongst participants with only a single pathogen detected, 37 were V. cholerae, 32 were ETEC, and 22 were Cryptosporidium. The distribution of single pathogen detection is shown in Fig. 1. Amongst all study participants, 38\% $(103 / 269)$ were positive for toxigenic $V$. cholerae with men 16-81 years being the demographic group with the highest prevalence at $52 \%$. The other most common enteric pathogens detected were Cryptosporidium (28\%, 74/269), Enterotoxigenic Escherichia coli (36\%, 96/269), Shigella (16\%, 43/269), and Campylobacter (17\%, 45/ 269). Forty-five percent of participants carried multiple pathogens (two or more).

Girls 1-15 years had the highest prevalence of carrying multiple pathogens and a fifth of all boys $1-15$ years carried three pathogens. Our study detected one boy aged 1-15 years who tested positive for rotavirus. Our study could not detect any enteric pathogen for $16 \%$ of the study population. Table 1 refers to the prevalence with 95\% confidence intervals of individual pathogens stratified by the demographic group.
Our study participants carried a mean of 1.6 pathogens per patient and up to eight different pathogens were detected in a single patient (Interquartile range $=1$ ). Boys and girls 1-15 years carried a greater number of pathogens than adults. There was some evidence indicating boys $1-15$ years carried 1.47 (95\%CI: 1.13-1.92; $p=$ $0.004)$ times the number of pathogens than women 1681 years. Likewise, girls $1-15$ years carried $1.6(95 \% \mathrm{CI}$ : $1.27-2.02 ; p<0.001)$ times the number of pathogens than adult women. Table 2 presents the mean number of pathogens by demographic groups.

\section{Comparison of cholera detection by stool-based multiplex-PCR and Crystal VC RDT}

Of the 269 study participants, 17 (6\%) were RDTpositive for $V$. cholerae $\mathrm{O} 1$ but negative for toxigenic $V$. cholerae via PCR and inversely, 19 (7\%) were positive via PCR but RDT-negative. There was no evidence suggesting a difference in homogeneity (McNemar's $x^{2} p=$ $0.74)$.

\section{Discussion}

All study participants were admitted to the Uvira CTC with suspected cholera, as defined by acute diarrhea, but only $38 \%(103 / 269)$ were positive for $V$. cholerae by rectal swab-based multiplex-PCR analysis. Among the participants, 11 different non-cholera enteric pathogens were detected; of which, ETEC (36\%) and Cryptosporidium $(28 \%)$ were the two most prevalent. Eighty-three percent of participants had at least one of the 15 assessed pathogens and almost half $(45 \%, 122 / 269)$ were

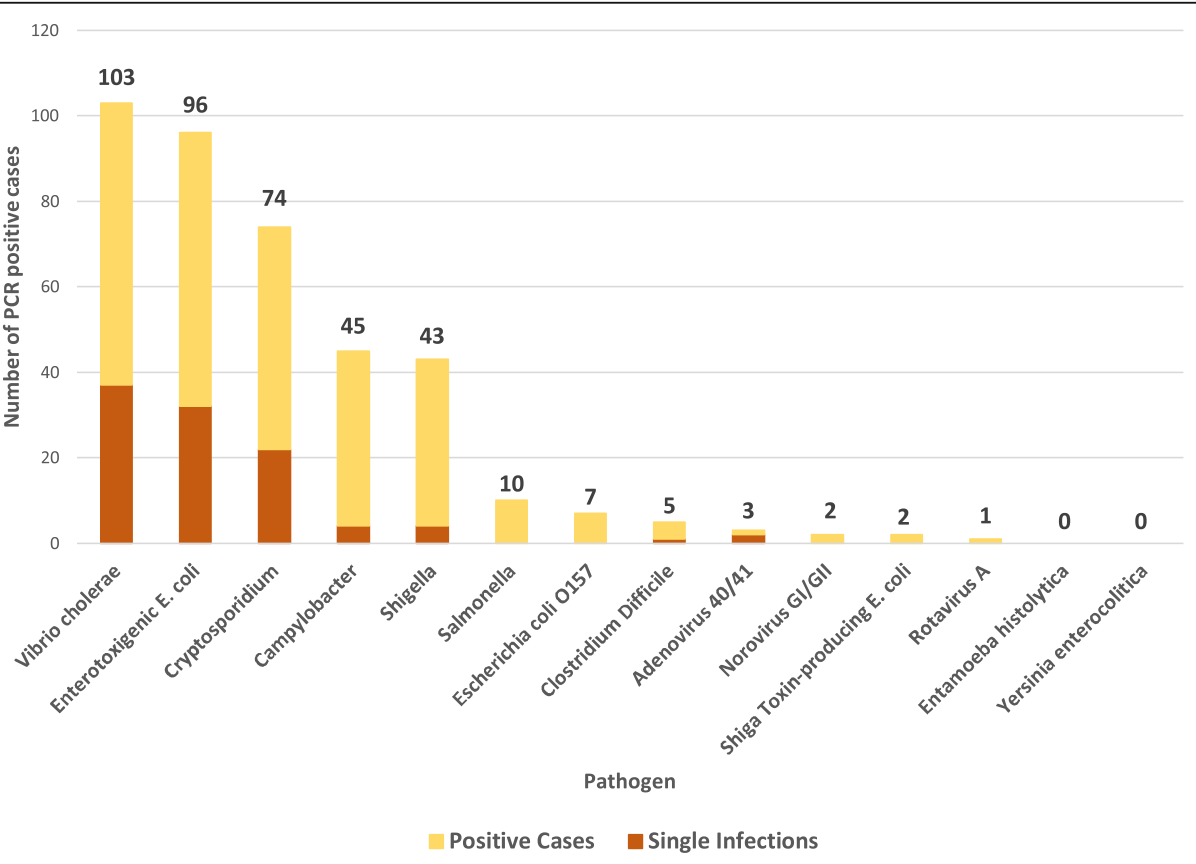

Fig. 1 Frequency of specific enteric pathogens detection among enrolled CTC patients 
Table 1 Prevalence of enteric pathogens by age and sex demographic group

\begin{tabular}{|c|c|c|c|c|c|}
\hline \multirow[t]{2}{*}{ Enteric Pathogen } & \multicolumn{5}{|c|}{ Prevalence (95\% Confidence Interval) } \\
\hline & Total enrolled & Boys $1-15$ years & Men $16-81$ years & Girls $1-15$ years & Women $16-81$ years \\
\hline Total Samples & 269 & 54 & 83 & 47 & 85 \\
\hline At least one pathogen positive & $83.6 \%(78.7-87.6)$ & $85.2 \%(72.7-92.5)$ & $83.1 \%(73.3-89.8)$ & $89.4 \%(76.4-95.6)$ & $80.0 \%(70.0-87.3)$ \\
\hline Bacteria & $73.9 \%(68.4-78.9)$ & $68.5 \%(54.7-79.7)$ & $75.9 \%(65.4-84.0)$ & $78.7 \%(64.4-88.3)$ & $72.9 \%(62.4-81.4)$ \\
\hline Toxigenic Vibrio cholerae & $38.3 \%(32.6-44.3)$ & $25.9 \%(15.8-39.5)$ & $51.8 \%(41.0-62.5)$ & $38.3 \%(25.3-53.2)$ & $32.9 \%(23.7-43.7)$ \\
\hline Enterotoxigenic E. coli & $35.7 \%(30.2-41.6)$ & $40.7 \%(28.3-54.5)$ & $30.1 \%(21.1-41.0)$ & $38.3 \%(25.3-53.2)$ & $36.5 \%(26.8-47.3)$ \\
\hline Campylobacter & $16.7 \%(12.7-21.7)$ & $27.8 \%(17.3-41.4)$ & $10.8 \%(5.7-19.7)$ & $29.8 \%(18.3-44.6)$ & $8.2 \%(3.9-16.4)$ \\
\hline Shigella & $16.0 \%(12.1-20.9)$ & $24.1 \%(14.3-37.5)$ & $14.5 \%(8.3-23.9)$ & $23.4 \%(13.2-37.9)$ & $8.2 \%(3.9-16.4)$ \\
\hline Salmonella & $3.7 \%(2.0-6.8)$ & $3.7 \%(0.9-14.0)$ & $2.4 \%(0.6-9.4)$ & $4.3 \%(1.0-16.0)$ & $4.7 \%(1.8-12.0)$ \\
\hline Escherichia coli O157 & $2.5 \%(1.3-5.4)$ & $1.9 \%(0.2-12.5)$ & $2.5 \%(0.6-9.5)$ & $6.4 \%(2.0-18.5)$ & $1.2 \%(0.1-8.1)$ \\
\hline Clostridium difficile & $1.9 \%(0.8-4.4)$ & $1.9 \%(0.2-12.5)$ & - & $2.1 \%(0.3-14.3)$ & $3.5 \%(1.1-10.5)$ \\
\hline Shiga Toxin-producing E. coli & $0.7 \%(0.2-2.9)$ & - & - & $2.1 \%(0.3-14.3)$ & $1.2 \%(0.02-8.1)$ \\
\hline Yersinia enterocolitica & - & - & - & - & - \\
\hline Viruses & $2.2 \%(1.0-4.9)$ & $5.6 \%(1.8-16.2)$ & - & $2.1 \%(0.3-14.3)$ & $2.4 \%(0.6-9.1)$ \\
\hline Adenovirus 40/41 & $1.1 \%(0.4-3.4)$ & $1.8 \%(0.2-12.5)$ & - & $2.1 \%(0.3-14.3)$ & $1.2 \%(0.2-8.1)$ \\
\hline Norovirus Gl/Gll & $0.7 \%(0.2-2.9)$ & $18.5 \%(0.2-12.5)$ & - & - & $1.2 \%(0.2-8.1)$ \\
\hline Rotavirus A & $0.4 \%(0.1-2.6)$ & $1.9 \%(0.2-12.5)$ & - & - & - \\
\hline Parasites & $27.5 \%(22.5-33.2)$ & $35.2 \%(23.5-49.0)$ & $26.5 \%(18.0-37.2)$ & $29.8 \%(18.3-44.6)$ & $22.4 \%(14.6-32.6)$ \\
\hline Cryptosporidium & $27.5 \%(22.5-33.2)$ & $35.2 \%(23.5-49.0)$ & $26.5 \%(18.0-37.2)$ & $29.8 \%(18.3-44.6)$ & $22.4 \%(14.6-32.6)$ \\
\hline Entamoeba histolytica & - & - & - & - & - \\
\hline \multicolumn{6}{|l|}{ Pathogen Diversity } \\
\hline No pathogens & $16.4 \%(12.4-21.3)$ & $14.8 \%(7.5-27.3)$ & $16.9 \%(10.2-26.7)$ & $10.6 \%(4.4-23.6)$ & $20.0 \%(12.7-30.0)$ \\
\hline Single pathogen & $38.3 \%(32.6-44.3)$ & $35.2 \%(23.5-49.0)$ & $41.0 \%(30.8-52.0)$ & $21.3 \%(11.6-35.6)$ & $47.1 \%(36.6-57.8)$ \\
\hline 2 pathogens & $25.6 \%(20.8-31.2)$ & $18.5 \%(10.1-31.5)$ & $26.5 \%(18.0-37.2)$ & $36.2 \%(23.5-51.1)$ & $23.5 \%(15.6-33.8)$ \\
\hline 3 pathogens & $14.9 \%(11.1-19.7)$ & $22.2 \%(12.9-35.5)$ & $12.0 \%(6.5-21.1)$ & $23.5 \%(13.2-37.9)$ & $8.2 \%(3.9-16.4)$ \\
\hline 4 pathogens & $3.7 \%$ (2.0-6.8) & $7.4 \%(2.7-18.5)$ & $3.6 \%(1.2-10.8)$ & $6.4 \%(2.0-18.5)$ & - \\
\hline 5 pathogens & $0.7 \%(0.2-2.9)$ & - & - & $2.1 \%(0.3-1.4)$ & $1.2 \%(0.2-8.1)$ \\
\hline 6 pathogens & - & - & - & - & - \\
\hline 7 pathogens & - & - & - & - & - \\
\hline 8 pathogens & $0.4 \%(0.1-2.6)$ & $1.9 \%(0.2-12.5)$ & - & - & - \\
\hline
\end{tabular}

Table 2 Mean number of pathogens detected among enrolled CTC patients, stratified by age and sex

\begin{tabular}{|c|c|c|c|c|}
\hline Count Data Model & Estimated No. of Pathogens Carried & Standard Deviation & Unadjusted IRR* $(95 \% \mathrm{Cl})$ & $p$ Value \\
\hline Total & 1.56 & & & \\
\hline All males & 1.60 & 1.23 & $1.05(0.88-1.26)$ & 0.35 \\
\hline Boys $1-15$ years & 1.83 & 1.46 & $1.47(1.13-1.92)$ & 0.004 \\
\hline Men 16-81 years & 1.45 & 1.03 & $1.16(0.93-1.45)$ & 0.19 \\
\hline All females & 1.50 & 1.12 & Reference** & \\
\hline Girls $1-15$ years & 2.0 & 0.95 & $1.60(1.27-2.02)$ & $<0.001$ \\
\hline Women 16-81 years & 1.52 & 1.09 & Reference & \\
\hline
\end{tabular}


carriers for multiple pathogens i.e. two or more enteric pathogens. Up to eight different pathogens were detected in a single patient. Pathogen diversity was highest among male and female children (age 1-15 years) and lowest among adult women (age 16-81 years).

Our results on cholera confirmation are similar to those of the multi-site AFRICHOL study [31] and suggest that cholera burden in the DRC may be lower than previously estimated. Our PCR results with regard to cholera detection are comparable to results obtained using a commercial RDT among a similar study population [19]. Despite finding no evidence for a significant difference between these two methods (McNemar's test $p=0.7), 7 \%$ of study participants were PCR positive but RDT negative and $6 \%$ were RDT positive and PCR negative. This could be explained by the performance of the two tests as neither are a gold standard; xTAG GPP methods have $100 \%$ specificity but do not have a validated sensitivity (Luminex Corporation, Austin TX, USA) and Crystal VC RDT has a cholera detection sensitivity and specificity of 93 and $91 \%$ respectively (Crystal VC, Span Diagnostics, Surat, India). The discrepancies between the PCR and RDT results could also partly be due to the detection of non-toxigenic $V$. cholerae $\mathrm{O} 1$ by $\mathrm{RDT}$, although, the proportion of these strains is estimated to be less than $5 \%$ in similar contexts [20]. Discrepancies may also be caused by the detection of toxigenic non-O1/O139 V. cholerae by PCR. However, the likelihood of having toxigenic strains of serogroups other than $\mathrm{O} 1$ or $\mathrm{O} 139$, even though they have been implicated as a cause of cholera-like outbreaks [32, 33], is low and has not been reported in a similar epidemiological context. The majority of concordant pairs in RDT/PCR results suggests nonetheless that the $V$. cholerae strains detected were toxigenic $\mathrm{O} 1$.

A recent multi-country study for the etiology of moderate to severe diarrhea in children under five years showed the proportion of diarrheal disease attributable to $V$. cholerae increased as age increased [2,34]. Another study for the change in enteric pathogen prevalence during floods showed the prevalence of toxigenic $V$. cholerae was higher in adults than children [35]. In our own study, we found a higher proportion of $V$. cholerae pathogens in adults than in children, and children carried more pathogens than adults. Current literature also suggests that enteric infections can be asymptomatic as seen in the re-analysis of the GEMS case-control study [34, 36] Infections with Campylobacter, Cryptosporidium, and ETEC were often not associated with diarrhea in children under five, and the same study indicates diarrhea could be explained by the combined presence of multiple pathogens or that the severity of a diarrheal illness increases when multiple pathogens are present [34, $36,37]$. In the re-analysis of the MAL-ED birth-cohort study, clinical presentation of illness was also modified when a child had co-infections [38]. Furthermore, both ETEC and Shigella have been shown to have long-term growth deficits and Cryptosporidium can affect growth even in asymptomatic people [38, 39]. Our results show a mean number of nearly 1.6 pathogens in participants of all ages and all considered as suspected cholera cases. Regardless of causality, these pathogens potentially have positive associations with each other and may increase the severity of diarrheal symptoms.

ETEC and V. cholerae represented the majority of detected pathogens in our participants. Both cause profuse watery diarrhea and severe dehydration and are often mis-diagnosed in the absence of laboratory diagnosis [35]. The pathogens included in this study share fecaloral transmission pathways, either water-borne or waterwashed [40] and continued improvements on WASH infrastructure and access to safe drinking water could reduce the main transmission routes of many of these pathogens. Only one case of rotavirus was detected in our samples, although the burden attributed to rotavirus in LMICs is reportedly high [1]. Two possible reasons for this are: rotavirus most commonly infects children under the age of five, an age group for which we had few participants; preservation on FTA Elute cards and storage may also have had more detrimental effect on viral DNA/RNA than on other pathogen's nucleic acids.

\section{Limitations}

There are a number of limitations to this study. First, our study only included people admitted to the CTC and, therefore, does not capture symptomatic cholera cases who do not seek care or asymptomatic carriers $[10,41]$. Secondly, we opted to use rectal swabs for sampling, instead of direct stool, to mitigate the high risk of cross-contamination or contact with chlorine. A previous study found rectal swabs had similar detection rates when compared to direct stool samples during PCR analysis [42]. Storing samples on FTA elute cards for the Luminex PCR assay has yet to be validated; although, multiple studies have described FTA elute cards as a comparable preservation method when compared to fresh and frozen samples [21, 43]. Literature also suggests there are no signs of nucleic acid degradation with short-term storage on elute cards; however prolonged preservation, humidity, and high temperatures may negatively impact nucleic acid preservation, particularly with RNA [21, 43-45]. In our study, viral pathogens were lower than expected, which could be attributed to viral nucleic acid degradation. This may explain why rotavirus was detected in only one sample. Therefore, negative results should be interpreted with caution. Giardia was found by the manufacturer to cross-react with other organisms in stool samples and accurate 
detection would have required a follow-up identification method for all positive samples, which was not possible in our study. Therefore, Giardia detections results were not included in the statistical analysis. No fungal pathogens are targeted by the Luminex xTAG GPP. Luminex $\mathrm{xTAG}^{\circ}$ GPP detects toxigenic $V$. cholerae strains while Crystal $^{\circ}$ VC RDT detects O1/O139 antigens of $V$. cholerae strains. Therefore, we were not able to conclude whether testing performance or variety of $V$. cholerae strains are leading to discordant results between both methods and we may not be detecting non-toxigenic non-O1/non-O139 strains that can be responsible for diarrhea. Finally, to determine the pathogens truly associated with acute diarrheal disease amongst admitted CTC patients would have required a different study design and the use of quantitative PCR methods to assess the etiological quantity of detected pathogens [46]; however, in the circumstance of acute diarrhea, single pathogen detection is likely sufficient to determine enteric infections [47] as symptomatic individuals typically shed a higher quantity of pathogens [47-49].

\section{Conclusions}

Our finding that more than half the patients admitted to a CTC were not positive for cholera by stool-based PCR and RDT assays are consistent with previous results in DRC and other cholera endemic areas of sub-Sahara Africa. However, the prevalence of the assessed enteric pathogens was high among patients admitted to the Uvira CTC with $84 \%$ having at least one of the 15 assessed pathogens, and $45 \%$ carrying multiple pathogens. Our findings lend support to the current strategy of the DRC Ministry of Health for the prevention and control of cholera, which targets "hotspot" areas such as North and South Kivu, and encourages future actions to continue with a comprehensive strategy that includes both improved water, sanitation and hygiene and effective and timely treatment of cases.

\section{Supplementary information}

Supplementary information accompanies this paper at https://doi.org/10 1186/s12879-020-05454-0.

\section{Additional file 1.}

\section{Acknowledgements}

We thank all the CTC staff who contributed to this study, as well as the Uvira district head doctor (MCZ) in Uvira, Dr. P. Nimi, and the provincial health division (DPS) in Bukavu. We are also grateful to OXFAM GB staff for their invaluable support in Uvira. In addition, we truly appreciate the valuable inputs provided by M. Lemenager and F. Bedecarrats from the Agence Francaise de Development and T. Vandevelde, T. Constant and D. Machuel from the Veolia Foundation during the study.

\section{Authors' contributions}

CW, AJ and OC designed the study. BR and JS recruited participants and performed cholera RDTs. All laboratory analysis was conducted by CW, LG and CD. Statistical analysis was performed by CW, AJ and DG. All authors read and approved the final manuscript.

\section{Funding}

This study was funded by the Agence Française de Dévelopment and the Veolia Foundation. The funders had no role in study design, data collection and analysis, decision to publish, or preparation of the manuscript.

\section{Availability of data and materials}

All data generated and analyzed during this study are included in the published manuscript and supplementary information files.

\section{Ethics approval and consent to participate}

Informed written consent was provided by all study participants unless under the age of fifteen, in which case consent was sought from an accompanying parent or guardian. A participant information sheet (PIS) was provided in Swahili and retained by the participant. If the participant was unable to read, the PIS was read to them in full and verbal consent recorded by the laboratory technician and an independent, i.e. an individual not associated with the study team, third-party witness; this procedure was approved by both ethics committees below.

Ethical approval for this study was provided by the Ethics Committee of the School of Public Health of Kinshasa (No 88c/2017) and the Research Ethics Committee of the London School of Hygiene and Tropical Medicine (LSHTM) (Ref: 15193). Authorization to collect, preserve, ship, and analyze the Whatman Elute cards at LSHTM was granted by the Ministry of Health for DRC through a Material Transfer Agreement. The associated Uvira Trial is registered at clinicaltrials.gov (Ref: NCT02928341).

Consent for publication

Not applicable.

\section{Competing interests}

The authors declare that they have no competing interests.

\section{Author details}

'Department of Disease Control, Faculty of Infectious and Tropical Diseases, London School of Hygiene and Tropical Medicine, Keppel Street, London WC1E 7HT, UK. ${ }^{2}$ Department of Infection Biology, Faculty of Infectious and Tropical Diseases, London School of Hygiene and Tropical Medicine, London, UK. ${ }^{3}$ Ministère de la Santé Publique, Division Provinciale de la Santé Publique, District Sanitaire d'Uvira, Uvira, Sud-Kivu, Congo. ${ }^{4}$ Department of Infectious Disease Epidemiology, Faculty of Epidemiology and Population Health, London School of Hygiene and Tropical Medicine, London, UK.

Received: 22 July 2019 Accepted: 24 September 2020

Published online: 09 October 2020

\section{References}

1. Troeger C, Blacker BF, Khalil IA, Rao PC, Cao S, Zimsen SR, et al. Estimates of the global, regional, and national morbidity, mortality, and aetiologies of diarrhoea in 195 countries: a systematic analysis for the Global Burden of Disease Study 2016. Lancet Infect Dis. 2018;18:1211-28 Available from: http://dx.doi.org/10.1016 [cited 201825 Oct].

2. Kotloff KL, Nataro JP, Blackwelder WC, Nasrin D, Farag TH, Panchalingam S, et al. Burden and aetiology of diarrhoeal disease in infants and young children in developing countries (the Global Enteric Multicenter Study, GEMS): a prospective, case-control study. Lancet. 2013;382:209-22 Available 
from: https://www.thelancet.com/pdfs/journals/lancet/PIIS0140-6736(13 )60844-2.pdf [cited 201816 Jun].

3. Amour C, Gratz J, Mduma ER, Svensen E, Rogawski ET, McGrath M, et al. Epidemiology and Impact of Campylobacter Infection in Children in 8 LowResource Settings: Results from the MAL-ED Study. Clin Infect Dis. 2016; 63(9):1171-9 Available from: https://academic.oup.com/cid/articleabstract/63/9/1171/2576661 [cited 20187 Aug].

4. MAL-ED Network Investigators. Early childhood cognitive development is affected by interactions among illness, diet, enteropathogens and the home environment: findings from the MAL-ED birth cohort study. BMJ Glob Health. 2018;3:752 Available from: https://doi.org/10.1136/bmjgh-2018000752 [cited 201813 Dec].

5. Wagner $E G$, Lanoix J. Excreta disposal for rural areas and small communities. Monogr Ser. 1958;39:1-182.

6. Federspiel F, Ali M. The cholera outbreak in Yemen: lessons learned and way forward. BMC Public Health. 2018;18(1338) Available from: https://doi. org/10.1186/s12889-018-6227-6. [cited 201915 Jan].

7. Ali M, Nelson AR, Lena Lopez A, Sack DA. Updated Global Burden of Cholera in Endemic Countries. PLoS Negl Trop Dis. 2015;9(6) Available from: https://journals.plos.org/plosntds/article/file?id=10.1371/journal.pntd.0003 832\&type=printable [cited 20185 Aug].

8. The Global Task Force on Cholera Control. Ending Cholera: A Global Roadmap to 2030. 2017. Available from: http://www.who.int/cholera/ publications/global-roadmap.pdf?ua=1 [cited 20185 Oct]

9. Hartley DM, Glenn Morris J Jr, Smith DL. Hyperinfectivity: a critical element in the ability of V. cholerae to cause epidemics? PLoS Med. 2005;3(1):0063-9.

10. Nelson EJ, Harris JB, Glenn Morris J Jr, Calderwood SB, Camilli A. Cholera transmission: the host, pathogen and bacteriophage dynamic. Nat Rev Microbiol. 2009;7(10).

11. Griffith DC, Kelly-Hope LA, Miller MA. Review of reported cholera outbreaks worldwide, 1995-2005. Am J Trop Med Hyg. 2006;75(5):973-7.

12. Lessler J, Moore SM, Luquero FJ, Mckay HS, Grais R, Henkens M, et al. Articles Mapping the burden of cholera in sub-Saharan Africa and implications for control: an analysis of data across geographical scales. Lancet. 2018;391:1908-15 Available from: http://dx.doi.org/10.1016 [cited 201826 Oct].

13. World Health Organization. Meeting of the Strategic Advisory Group of Experts on Immunization, October 2018-- Conclusions and recommendations. Geneva; 2018. Available from: http://www.who.int/wer2 018,93,661-680No49 [cited 201921 Feb].

14. Ciglenecki I, Azman AS, Jamet C, Serafini M, Luquero FJ, Cabrol J-C. Progress and challenges in using Oral cholera vaccines to control outbreaks: The Medicins sans Frontieres experience. JID. 2018;218(3):165-6.

15. von Seidlein $L$, Deen JL. Preventing cholera outbreaks through early targeted interventions. PLoS Med. 2018;15(2):e1002510 Available from: http://dx.plos.org/10.1371/journal.pmed.1002510 [cited 201811 Oct]

16. ClinicalTrials.gov Impact Evaluation of Urban Water Supply Improvements on Cholera and Other Diarrhoeal Diseases in Uvira, Democratic Republic of Congo Identifier: NCT02928341 [Internet]. NIH Clinical Trials. 2016 [cited 2019 Feb 15]. Available from: https://clinicaltrials.gov/ct2/show/NCT0292 8341?cond=impact+evaluation+of+urban+water+supply+ improvements\&rank=1.

17. Bompangue D, Giraudoux P, Piarroux M, Mutombo G, Shamavu R, Sudre B, et al. Cholera Epidemics, War and Disasters around Goma and Lake Kivu: An Eight-Year Survey. PLoS Negl Trop Dis. 2009;3(5).

18. Rebaudet S, Sudre B, Faucher B, Piarroux R. Environmental determinants of Cholera Outbreaks in Inland Africa: A Systematic Review of Main Transmission Foci and Propagation Routes. J Infect Dis. 2013;208(S1):S46-54 Available from: https://watermark.silverchair.com/jit195.pdf?token= AQECAHi208BE490oan9kkhW_Ercy7Dm3ZL_9Cf3qfKAc485 ysgAAAdswggHXBgkqhkiG9w0BBwagggHIMIIBXAIBADCCAb0GCSqGSIb3 DQEHATAeBglghkgBZQMEAS4wEQQMrm0aiUlaK5 WFyecmAgEQgllBjg|kleiRPLH7eaz2ZCPzJbb_vZmXrZX1oCUpcc7bF-ArG1HV [cited 201813 Aug].

19. Jeandron A, Cumming O, Rumedeka BB, Saidi JM, Cousens S. Confirmation of cholera by rapid diagnostic test amongst patients admitted to the cholera treatment Centre in Uvira, Democratic Republic of the Congo. PLoS One. 2018;13(8) Available from: https://doi.org/10.1371/journal.pone. 0201306.

20. Bhuiyan NA, Qadri F, Faruque ASG, Malek MA, Salam MA, Nato F, et al. Use of Dipsticks for Rapid Diagnosis of Cholera Caused by Vibrio cholerae 01 and O139 from Rectal Swabs. J Clin Microbiol. 2003;41(8):3939-41 Available from: https://www.ncbi.nlm.nih.gov/pmc/articles/PMC179818/pdf/0384.pdf [cited $201826 \mathrm{Jul}]$.

21. Lalani T, Tisdale MD, Maguire JD, Wongsrichanalai C, Riddle MS, Tribble DR. Detection of enteropathogens associated with travelers' diarrhea using a multiplex Luminex-based assay performed on stool samples smeared on Whatman FTA elute cards. Diagn Microbiol Infect Dis. 2015;83(1):18-20.

22. Luminex Molecular Diagnostics Inc. IVD XTAG ${ }^{\bullet}$ gastrointestinal pathogen panel MLD-032-KPI-002 rev H. Toronto, ON, Canada; 2017. Available from: www.luminexcorp.com.

23. Khare R, Espy MJ, Cebelinski E, Boxrud D, Sloan LM, Cunningham SA, et al. Comparative evaluation of two commercial multiplex panels for detection of gastrointestinal pathogens by use of clinical stool specimens. J Clin Microbiol. 2014;52(10):3667-73 Available from: http://www.ncbi.nlm.nih.gov/ pubmed/25100818 [cited 201917 Feb].

24. Perry MD, Corden SA, Howe RA. Evaluation of the Luminex xTAG gastrointestinal pathogen panel and the Savyon diagnostics gastrointestinal infection panel for the detection of enteric pathogens in clinical samples. J Med Microbiol. 2014;63:1419-26.

25. Navidad JF, Griswold DJ, Gradus MS, Bhattacharyya S. Evaluation of Luminex xTAG Gastrointestinal Pathogen Analyte-Specific Reagents for HighThroughput, Simultaneous Detection of Bacteria, Viruses, and Parasites of Clinical and Public Health Importance. J Clin Microbiol. 2013;51(9):3018-24 Available from: http://dx.doi.org/10.1128 [cited 201917 Feb].

26. Becker SL, Chatigre JK, Gohou J-P, Coulibaly JT, Leuppi R, Polman K, et al. Combined stool-based multiplex PCR and microscopy for enhanced pathogen detection in patients with persistent diarrhoea and asymptomatic controls from Côte d'Ivoire. Clin Microbiol Infect. 2015;21:591.e1-591.e10 Available from: https://doi.org/10.1016/j.cmi.2015.02.016 [cited 201917 Feb].

27. Eibach D, Krumkamp R, Hahn A, Sarpong N, Adu-Sarkodie Y, Leva A, et al. Application of a multiplex PCR assay for the detection of gastrointestinal pathogens in a rural African setting. BMC Infect Dis. 2016;16(1):150 Available from: http://bmcinfectdis.biomedcentral.com/articles/10.1186/s1 2879-016-14 81-7 [cited 20184 Sep].

28. GE Life Sciences. Whatman FTA Elute Data file 28-9844-02 AA. Buckinhamshire, UK; 2011. p. 2-5.

29. Cameron AC, Trivedi PK. Microeconomics using Stata. Revised Ed. College Station, Texas: Stata Press; 2010. p. 572-6.

30. Tribble DR. Antibiotic Therapy for Acute Watery Diarrhea and Dysentery. Mil Med. 2017;182 Available from: http://content.ebscohost.com/ContentServer. asp?T=P\&P=AN\&K=125351926\&S=R\&D=aph\&EbscoContent= dGJyMNHr7ESep7U4xNvgOLCmr1Gep7RSr6u4 TLWWxWXS\&ContentCustomer=dGJyMPGrkivqbROuePfgeyx34Tq2\%2 BaH8eoA. Cited 2019 Feb 17.

31. Sauvageot D, Njanpop-Lafourcade B-M, Akilimali L, Anne J-C, Bidjada P, Bompangue $D$, et al. Cholera incidence and mortality in sub-Saharan African sites during multi-country surveillance. PLOS Neglected Top Dis. 2016;10(5): $1-16$.

32. Dorman MJ, Domman D, Uddin Ml, Sharmin S, Afrad MH, Begum YA, et al. High quality reference genomes for toxigenic and non-toxigenic Vibrio cholerae serogroup 0139. Available from: https://doi.org/10.1038/s41598019-41883-x [cited 202018 Aug].

33. Tobin-D M, Smith AR, Bulens SN, Thomas S, Hodel M, Izumiya H, et al. Severe Diarrhea Caused by Cholera Toxin-Producing Vibrio cholerae Serogroup O75 Infections Acquired in the Southeastern United States. 2008; 1035. Available from: https://academic.oup.com/cid/article/47/8/1035/344 811. Cited 2020 Aug 18.

34. Liu J, Platts-Mills JA, Juma J, Kabir F, Nkeze J, Okoi C, et al. Use of quantitative molecular diagnostic methods to identify causes of diarrhoea in children: a reanalysis of the GEMS case-control study. Lancet. 2016;388: 1291-301 Available from: https://ac.els-cdn.com/S014067361631529X/1-s2.0S014067361631529X-main.pdf?_tid=039b8d88-83c5-42f8-bc30-2c0af64718d3 \&acdnat=1529500966_989dd6ccc5503c7592e5651a79c9b804 [cited 2018 20].

35. Harris AM, Chowdhury F, Begum YA, Khan Al, Faruque ASG, Svennerholm A$\mathrm{M}$, et al. Shifting Prevalence of Major Diarrheal Pathogens in Patients Seeking Hospital Care during Floods in in Dhaka, Bangladesh. Am J Trop Med Hyg. 2008;79(5):708-14 Available from: http://www.ajtmh.org/ docserver/fulltext/14761645/79/5/0790708.pdf?expires=15501795878id= id\&accname=guest\&checksum=C43D6FA09F14BD06AEAD4ACDD81 AAFEE [cited 201914 Feb]. 
36. Andersson M, Kabayiza J-C, Elfving K, Nilsson S, Msellem Ml, Artensson AM, et al. Coinfection with Enteric Pathogens in East African Children with Acute Gastroenteritis-Associations and Interpretations. Am J Trop Med Hyg. 2018; 98(6):1566-70 Available from: http://www.ajtmh.org.ez.lshtm.ac.uk/ docserver/fulltext/14761645/98/6/tpmd170473.pdf?expires $=15450498328 \mathrm{id}=$ id\&accname $=11868 \&$ checksum=0ACD9051A1B61D961E6147AE208C8AA3 [cited 201817 Dec].

37. Levine MM, Robins-Browne RM. Factors That Explain Excretion of Enteric Pathogens by Persons Without Diarrhea. Clin Infect Dis. 2012x;55(4):303-11 Available from: https:/www.ncbi.nlm.nih.gov/pmc/articles/PMC3502317/ pdf/cis789.pdf [cited 201817 Dec].

38. Platts-Mills JA, Liu J, Rogawski ET, Kabir F, Lertsethtakarn P, Siguas M, et al. Use of quantitative molecular diagnostic methods to assess the aetiology, burden, and clinical characteristics of diarrhoea in children in low-resource settings: a reanalysis of the MAL-ED cohort study. Lancet Glob Health. 2018: 6(12):e1309-18 Available from: https://linkinghub.elsevier.com/retrieve/pii/ S2214109X18303498 [cited 201813 Dec].

39. Kosek MN, Ahmed T, Bhutta Z, Caulfield L, Guerrant R, Houpt E, et al. Causal Pathways from Enteropathogens to Environmental Enteropathy: Findings from the MAL-ED Birth Cohort Study. EBioMedicine. 2017;18:109-17 Available from: http://linkinghub.elsevier.com/retrieve/pii/\$235239641730083 X [cited 201816 Jun].

40. Cairncross S, Feachem SR. Environmental Health Engineering in the Tropics: Water, Sanitation and Disease Control. In: Earthscan Water Text. Third. London: Routledge; 2018. p. 4-9.

41. Schaetti C, Sundaram N, Merten S, Ali SM, Nyambedha EO, Lapika B, et al. Comparing sociocultural features of cholera in three endemic African settings. BMC Med. 2013;11:1 Available from: http://www.biomedcentral. com/1741-7015/11/206 [cited 201918 Feb]

42. Kabayiza J-C, Andersson ME, Welinder-Olsson C, Bergström T, Muhirwa G, Lindh M. Comparison of rectal swabs and faeces for real-time PCR detection of enteric agents in Rwandan children with gastroenteritis. BMC Infect Dis. 2013;13(447) Available from: http://www.biomedcentral.com/14 71-2334/13/447 [cited 201914 Feb]

43. Lalani T, Tisdale MD, Liu J, Mitra I, Philip C, Odundo E, et al. Comparison of stool collection and storage on Whatman FTA Elute cards versus frozen stool for enteropathogen detection using the TaqMan ${ }^{\oplus}$ Array Card PCR assay. PLoS One. 2018;13(8):e0202178 Available from: https://doi.org/10. 1371/journal.pone.0202178 [cited 201914 Feb].

44. Lau H, Hurt AC. Assessment of the RNASound RNA Sampling Card for the Preservation of Influenza Virus RNA. Front Microbiol. 2016;7(1736) Available from: http://journal.frontiersin.org/article/10.3389/fmicb.2016.01736/full [cited 201918 Feb].

45. Jones $\mathrm{S}$, Sutherland $\mathrm{CJ}$, Hermsen $\mathrm{C}$, Arens $\mathrm{T}$, Teelen $\mathrm{K}$, Hallett R, et al. Filter paper collection of Plasmodium falciparum mRNA for detecting low-density gametocytes. Malar J. 2012;11(266) Available from: http://www. malariajournal.com/content/11/1/266 [cited $201914 \mathrm{Mar}$ ].

46. Rogawski ET, Platts-Mills JA, Liu J, Operario DJ, Taniuchi M, Gratz JM, et al. Use of quantitative molecular diagnostic methods to investigate the effect of enteropathogen infections on linear growth in children in low-resource settings: longitudinal analysis of results from the MAL-ED cohort study. Lancet Glob Health. 2018:6:1319-47.

47. Liu J, Gratz J, Amour C, Nshama R, Walongo T, Maro A, et al. Optimization of quantitative PCR methods for Enteropathogen detection. PLoS One. 2016; 11(6):e0158199.

48. Platts-Mills JA, Gratz J, Mduma E, Svensen E, Amour C, Liu J, et al. Association Between Stool Enteropathogen Quantity and Disease in Tanzanian Children Using TagMan Array Cards: A Nested Case-Control Study. Am J Trop Med Hyg. 2014;90(1):133-8 Available from: http://www. ajtmh.org/docserver/fulltext/14761645/90/1/133.pdf?expires=1550531393 \&id=id\&accname $=$ quest\&checksum $=$ DB65BE22CB51E480885C604876704FAC [cited 201918 Feb].

49. Kang G, Iturriza-Gomara M, Wheeler JG, Crystal P, Monica B, Ramani S, et al. Quantitation of Group A Rotavirus by Real-Time Reverse-Transcription-Polymerase Chain Reaction: Correlation With Clinical Severity in Children in South India. J Med Virol. 2004;74(1):118-22 Available from: https://www.ncbi.nlm.nih.gov/pmc/ articles/PMC2459214/pdf/ukmss-2081.pdf [cited 201918 Feb].

\section{Publisher's Note}

Springer Nature remains neutral with regard to jurisdictional claims in published maps and institutional affiliations.

Ready to submit your research? Choose BMC and benefit from:

- fast, convenient online submission

- thorough peer review by experienced researchers in your field

- rapid publication on acceptance

- support for research data, including large and complex data types

- gold Open Access which fosters wider collaboration and increased citations

- maximum visibility for your research: over $100 \mathrm{M}$ website views per year

At BMC, research is always in progress.

Learn more biomedcentral.com/submissions 